Gut, 1982, 23, 1077-1080

\title{
Overestimate of ${ }^{125} \mathrm{I}$-protein uptake from the adult mouse gut
}

\section{T SKOGH}

\section{From the Department of Medical Microbiology, University of Linköping, Linköping, Sweden}

SUMMARY Gastric instillation of ${ }^{125} \mathrm{I}$-labelled protein in mice leads to rapid appearance of blood radioactivity which is precipitable with $10 \%$ trichloroacetic acid (TCA). The same occurs when $\mathrm{Na}^{125} \mathrm{I}$ is given by mouth. Parenteral administration of non-radioactive NaI before feeding $\mathrm{Na}^{125} \mathrm{I}$ or ${ }^{125}$ I-labelled protein inhibits the appearance of TCA-precipitable radioactivity in the blood. The results presented in this study show that measurement of TCA-precipitable radioactivity in the blood after feeding ${ }^{125}$ I-labelled protein is not a reliable method for studying the passage of macromolecules across the gastrointestinal barriers unless an excess of iodide is given.

The functions of mucosal barriers in health and disease have attracted increasing interest in recent years. Extrinsically radiolabelled protein preparations have often been used for studying the passage of macromolecules through the gut wall. ${ }^{1-3}$ The amount of protein penetrating the mucosal barriers may be over-estimated when ${ }^{125}$ I-labelled protein preparations are used. ${ }^{4}$ Udall $e t a l^{5}$ have shown that small 'hot' fragments of radio-labelled protein can bind to native serum proteins. They suggest that small fragments arising from protein digestion in the gastrointestinal tract may bind to circulating plasma proteins, thereby simulating the passage of large molecules from the gut to the blood. The present study was undertaken to investigate whether or not measurement of trichloroacetic-acid-precipitable radioactivity in the blood after oral administration of ${ }^{125}$ I-labelled protein is a reliable model for studying the passage of protein across the gut mucosa.

\section{Methods}

ANIMALS

BALB/c mice of both sexes, aged 8-16 weeks, were used.

\section{CHEMICALS}

Carrier-free $\mathrm{Na}^{125} \mathrm{I}$ was obtained from Kabi Diagnostica, Nyköping, Sweden. Lyophilised human serum albumin (HSA) substituted with 35 dinitrophenyl (DNP) groups per molecule
(Calbiochem, La Jolla, Cal, USA) was dissolved in phosphate-buffered saline (PBS, pH7.6) and labelled with ${ }^{125} \mathrm{I}$ by the lactoperoxidase method. ${ }^{6} \mathrm{~A}$ final concentration of $1.4 \mathrm{mg} \mathrm{DNP}{ }_{35} \mathrm{HSA}$ per ml was used unless otherwise stated.

\section{ANTISERA}

IgG-anti-DNP from sera of rabbits immunised with DNP keyhole limpet haemocyanin was prepared and characterised as described elsewhere (in preparation), Fluorescein-isothiocyanate (FITC) -labelled sheep anti-rabbit IgG (Wellcome Reseach Laboratories, Beckenham, England) was used.

\section{EXPERIMENTAL PROCEDURES}

Mice kept fasting for approximately 18 hours were given intravenous injections of $0.5 \mathrm{ml}$ and subcutaneous injections of $2 \mathrm{ml} 0.15 \mathrm{M} \mathrm{NaCl}$ or $0.15 \mathrm{M}$ NaI. $0.5 \mathrm{ml}{ }^{125} \mathrm{I}-\mathrm{DNP}_{35} \mathrm{HSA}(0.7 \mathrm{mg})$ or 0.5 $\mathrm{ml} \mathrm{Na}{ }^{125} \mathrm{I}(0.05 \mathrm{mCi})$ was given via a gastric tube under light ether anaesthesia. The mice were allowed to awake with free access to water and food, and blood samples were taken from the retro-orbital vein plexus at regular time intervals. The blood was immediately transferred to $2 \mathrm{ml} 10 \%(\mathrm{w} / \mathrm{v})$ trichloroacetic acid. After 30 minutes or more at $+4^{\circ} \mathrm{C}$ the samples were resuspended in trichloroacetic acid and centrifuged again. Radioactivity in the pellets was measured in an Intertechnique Model CG30 gamma counter. For immunofluorescence experiments mice were given $0.1 \mathrm{ml}$ diluted $\mathrm{DNP}_{35} \mathrm{HSA}(0.8 \mathrm{mg} / \mathrm{ml})$ intravenously, or $0.5 \mathrm{ml}$ concentrated $(16 \mathrm{mg} / \mathrm{ml}) \mathrm{DNP}_{35} \mathrm{HSA}$ via a gastric tube. The animals were killed by decapitation after 15 minutes or three hours. The 
livers were removed and snap frozen in cold $\left(-70^{\circ} \mathrm{C}\right)$ methyl butane, and $5-\mu \mathrm{m}$ cryostat sections were cut. Rabbit IgG-anti-DNP was applied to the sections for 30 minutes in a moist chamber at room temperature. The slides were washed in PBS, and FITC-anti-rabbit IgG was then applied to the sections for a further 30 minutes. After washing in PBS the slides were mounted in PBS-buffered glycerine and examined in a Zeiss Model Standard microscope equipped with mercury lamp epiillumination (Osram HBO 50W) and filters for FITC activation/emission (2xKP 470, LP 455, FT 510, and LP 520). Photomicrographs were taken with Kodak Tri-X film.

\section{Results}

In mice given physiological saline before feeding $\mathrm{Na}^{125} \mathrm{I}(0.05 \mathrm{mCi})$, trichloroacetic-acid-precipitable radioactivity rapidly appeared in the blood (Fig. 1). Analysis of the radioactivity distribution in the blood after 15 minutes showed that more than $98 \%$ of the ${ }^{125}$ I-activity was confined to the plasma, and that about $40 \%$ of the total radioactivity was precipitable with trichloroacetic acid. No radioactivity peaks were recorded between the blood sampling occasions as measured continuously on

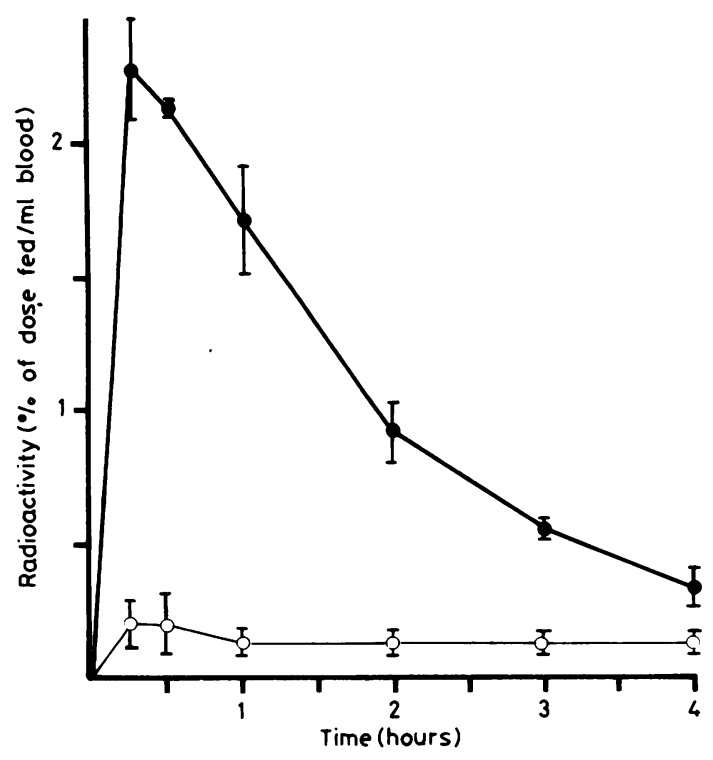

Fig. 1 Uptake of trichloroacetic acid-precipitable radioactivity into the blood of mice fed $0.5 \mathrm{ml}(0.05 \mathrm{mCi})$ $N a^{125}$ I after intravenous and subcutaneous injections of $(a)$ $0.15 \mathrm{M} \mathrm{NaCl}(\bullet-\bullet)$ and (b) 0.15M NaI (०-০). Each curve shows mean values (SEM) for three experiments. control animals using a non-invasive method described elsewhere. ${ }^{7}$ The appearance of trichloroacetic-acid-precipitable radioactivity in the blood was effectively inhibited in mice given $0 \cdot 15 \mathrm{M}$ $\mathrm{NaI}$ before feeding $\mathrm{Na}^{125} \mathrm{I}$ (Fig. 1).

When $0.7 \mathrm{mg}{ }^{125} \mathrm{I}-\mathrm{DNP}_{35} \mathrm{HSA}$ was fed to fasting mice, trichloroacetic-acid-precipitable radioactivity appeared very rapidly in the blood (Fig. 2). The blocking effect of 'cold' NaI was evident also in this experimental model (Fig. 2).

The immunofluorescence pattern of a liver 15 minutes after intravenous injection of $0.08 \mathrm{mg}$ $\mathrm{DNP}_{35} \mathrm{HSA}$ is shown in Fig. 3. By this time marked uptake by the non-parenchymal liver cells was evident. The same distribution was seen in livers examined three hours after the injection. When 8 mg $\mathrm{DNP}_{35} \mathrm{HSA}$ was given via a gastric tube no deposition of $\mathrm{DNP}_{35} \mathrm{HSA}$ could be detected in the livers by means of indirect immunofluorescence microscopy.

\section{Discussion}

Extrinsically radiolabelled proteins are often used to study the passage of intact macromolecules or large breakdown products across the gastrointestinal mucosa to the blood. After feeding ${ }^{125}$ I-labelled proteins to rats Hemmings and Williams ${ }^{3}$ found substantial amounts of tungstic-acid-precipitable radioactive material in the blood and in various tissues. Eight hours after oral administration of bovine IgG, $5 \%$ of the dose was tungstic-acidprecipitable in serum. André et $a l^{2}$ reported that approximately $2 \%(0.3 \% / \mathrm{ml})$ of an oral load of

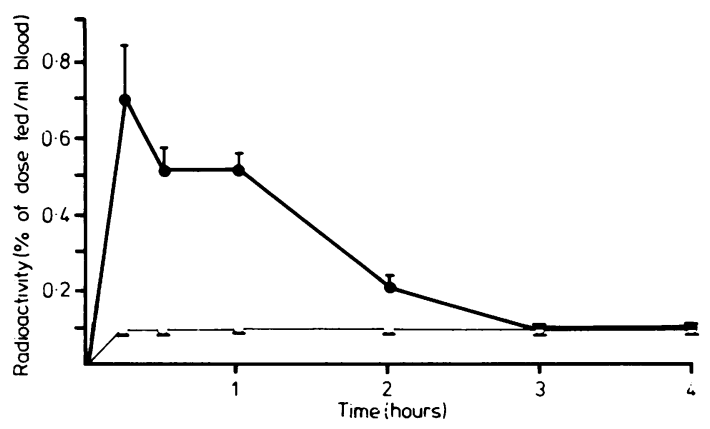

Fig. 2 Uptake of trichloroacetic acid-precipitable radioactivity into the blood of mice fed $0.5 \mathrm{ml}(0.7 \mathrm{mg})$ ${ }_{125}$ I-DNP ${ }_{35} H S A$ after intravenous and subcutaneous injections of (a) $0.15 \mathrm{M} \mathrm{NaCl}(\bullet-\bullet)$ and (b) $0.15 \mathrm{M} \mathrm{NaI}$ (०-०). Each curve shows mean values ( $\pm S E M)$ for three experiments. 
Fig. 3 Immunofluorescence corresponding to DNP groups within the non-parenchymal liver cells of a mouse 15 minutes after intravenous injection of $D N P_{35} H S A$ (original magnification $x 250$ ).

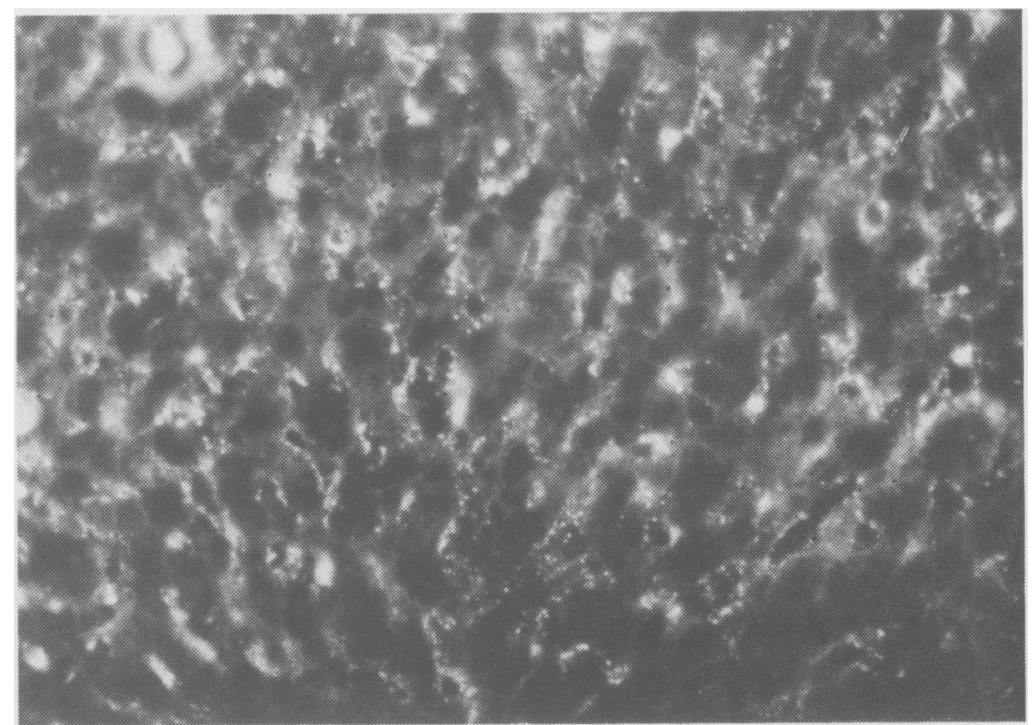

${ }^{125}$ I-HSA was found in the sera of rats two hours after feeding the substance. Warshaw et al $^{1}$ reported that $1-2 \%$ of the dose of extrinsically ${ }^{3} \mathrm{H}$-labelled bovine serum albumin was recovered from serum within three hours of intraduodenal administration in rats. In this study trichloroacetic-acid-precipitable radioactivity was found in the blood shortly after feeding ${ }^{125}$ I-labelled DNP ${ }_{35} \mathrm{HSA}$ to mice. The same occurred when $\mathrm{Na}^{125} \mathrm{I}$ was given. Lysis of the red blood cells by detergent before trichloroacetic-acidprecipitation did not affect the results (unpublished results). The amount of trichloroacetic-acidprecipitable radioactivity was drastically reduced when the animals were given non-radioactive $\mathrm{NaI}$ before the intragastric administration of ${ }^{125} \mathrm{I}$ $\mathrm{DNP}_{35} \mathrm{HSA}$ or $\mathrm{Na}^{125} \mathrm{I}$. It is probable that iodine, which is split off from the ${ }^{125}$ I-labelled protein by intestinal de-iodinases, ${ }^{89}$ passes across the gut wall and binds to circulating plasma proteins. It will then be possible to precipitate the radioactivity with trichloroacetic acid. The ${ }^{125} \mathrm{I}$-binding capacity is saturable and can be blocked by 'cold' NaI. The present results conflict with the findings of Jones ${ }^{10}$ who fed $\mathrm{Na}^{125} \mathrm{I}$, [ $\left.{ }^{125} \mathrm{I}\right]$ diiodotyrosine, or ${ }^{125}$ I-labelled proteins to suckling rats, and measured radioactivity in the sera after three hours; only after giving ${ }^{125}$ I-labelled proteins was the radioactivity precipitable with trichloroacetic acid.

Measuring the blood levels of trichloroacetic-acidprecipitable radioactivity after feeding ${ }^{125} \mathrm{I}$ $\mathrm{DNP}_{35} \mathrm{HSA}$ to mice pre-treated with 'cold' $\mathrm{NaI}$ disclosed no substantial transfer of intact protein from the gut to the blood. Even had transfer occurred, however, it would not have been possible to detect any significant amounts of intact protein in the blood, as $\mathrm{DNP}_{35} \mathrm{HSA}$ is cleared very rapidly from the circulation ${ }^{10}$ and becomes located mainly in the liver. ${ }^{11}$ Large quantities of $\mathrm{DNP}_{35} \mathrm{HSA}$ were therefore given orally to mice, and the livers were examined after three hours. By this time it could be expected from the results of others ${ }^{1-3}$ that at least $1 \%$ of the dose would have passed undegraded to the blood. In the present experiments this would correspond to an intravenous injection of $0.08 \mathrm{mg}$ DNP $_{35}$ HSA. When this dose was injected, immunofluorescence microscopy revealed massive uptake of $\mathrm{DNP}_{35} \mathrm{HSA}$ by the non-parenchymal liver cells both 15 minutes and three hours later. In contrast, indirect immunofluorescence microscopy showed no deposition whatsoever in the livers of mice fed $8 \mathrm{mg}$ $\mathrm{DNP}_{35} \mathrm{HSA}$. This observation supports the impression that uptake of intact protein by the normal gut is exceedingly small, and that it has been overestimated in many earlier reports. Nevertheless, it is quite possible that small fragments of dietary protein enter the blood stream, where they may bind to circulating plasma proteins. ${ }^{5}$ If such fragments possess antigenic determinants, immunological reactions may follow. In the present study dinitrobenzene groups were found in the urine after oral administration of $\mathrm{DNP}_{35} \mathrm{HSA}$ (unpublished observations). 
I wish to thank Dr Marcia Skogh for revising the English text. This study was supported by the Swedish Medical Research Council (grant 16X2183).

\section{References}

1 Warshaw AL, Walker WA, Isselbacher KJ. Protein uptake by the intestine: evidence for absorption of intact macromolecules. Gastroenterology 1974; 66: 987-94.

2 André C, Lambert R, Bazin H, Heremans JF. Interference of oral immunization with the intestinal absorption of heterologus albumin Eur J Immunol 1974; 4: 701-4.

3 Hemmings WA, Williams EW. Transport of large breakdown products of dietary protein through the gut wall. Gut 1978; 19: 715-23.

4 Tolo K, Brandtzaeg, Jonsen J. Mucosal penetration of antigen in the presence or absence of serum-derived antibody. An in vitro study of oral and intestinal mucosa. Immunology 1977; 33: 733-4.
5 Udall JN, Bloch KJ, Frietze L, Walker WA. Binding of exogenous protein fragments to native proteins: possible explanation for the overestimation of extrinsically labelled macromolecules from the gut. Immunology 1981; 42: 251-7.

6 Marchalonis JJ. An enzymic method for the trace iodination of immunoglobulins and other proteins. Biochem J 1969; 113: 299-305.

7 Skogh T, Edebo L, Sundqvist T. A non-invasive method for continuous measurement of gastrointestinal uptake and blood clearance. Z Versuchstierkal 1982; 24: 60-1.

8 Parkins RA, Dimitriadou A, Booth CC. The rates and sites of absorption of ${ }^{131}$ I-labelled albumin and sodium ${ }^{131}$ I in the rat Clin Sci 1960; 19: 595-604.

9 Jones RE. De-iodination of labelled proteins during intestinal transmission in the suckling rat. Proc $R$ Soc Lond B 1977; 99: 279-90.

10 Skogh T, Stendahl O, Sundquist T, Edebo L. Physiochemical properties and blood clearance of human serum albumin conjugated to different extents with dinitrophenyl groups. Int Arch Allergy Appl Immunol 1982. (In press.)

11 Skogh T. Tissue distribution of intravenously injected dinitrophenylated human serum albumin (DNP-HSA). Effects of specific IgG and IgA antibodies. Scand $J$ Immunol 1982. (In press.) 